the possible mixing up of the relics, but the excavations have been closely watched and studied by myself and several fellow-members of the local Archæological Society, and if there is one point clearer than another it is that there has been no such disturbance. The tree stumps in the overlying forest bed are as they grew, with their roots passing into the underlying strata, and everything indicates quiescence. Nor could the objects have sunk through the peat, for of the abundant stones in the overlying deposits, none have even penetrated the surface; the material is too compact to admit of this.

These interesting relics now form part of the extensive and ever-growing collection in the museum of the local Archæological and Antiquarian Society, the Société Jersiaise.

It would be interesting to know if any of your numerous archæological readers have found evidences of Neolithic man at this geological horizon.

Jersey, August 28.

J. Sinel.

The Structure of the Ciliary and Iris Muscles in Birds.

MAY I be allowed through your columns to direct the attention of physiologists and anatomists to certain special features in ocular accommodation, and in the movements of the iris in birds, and to a peculiarity of the ciliary muscle and sphincter of the pupil, which, so far as I have been able to ascertain, has not been previously described?

If the eye of any bird in which a light-coloured iris sharply contrasts with a black pupil be carefully watched, rapid changes in the size of the pupillary opening may be sometimes observed to take place during the few moments that the bird is fixedly looking at any object under the same intensity of illumination. Moreover, the character of these movements strongly suggests that they are under voluntary control.

The pupillary reaction to light is very rapid in birds; the recontraction following the transient dilation which accompanies the momentary closing and opening of the eyelids and nictitating membrane in the movement of blinking is so rapid that the contraction of the pupil seems to coincide with the re-opening of the eye, and not definitely to follow it as in man.

Atropine seems to have no effect in dilating, or Eserin in contracting, the pupil; neither does the former seem to affect accommodation in birds.

In connection with these facts it is also interesting to find that the ciliary muscle and the sphincter of the pupil in birds are both composed of striated fibres of the voluntary type, and not of plain unstriped muscle fibres as in man and other animals.

Thus, while in man with binocular vision the delicate movements of accommodation and the associated movements of the pupil are carried out by involuntary muscles, in birds, in which in many species vision is of the monocular type, the same movements are performed by voluntary muscles.

The extremely accurate and rapid movements of the beak in birds no doubt require a corresponding delicacy and rapidity of ocular accommodation at very short range.

Other interesting questions arise as to the representation of these intrinsic eye movements in the avian brain. The matter is also one of phylogenetic interest, and I hope to publish further histological details with photomicrographs of sections shortly.

Leicester, August 30 .

C. J. BOND.

\section{The Attacks of Birds upon Butterflies.}

Mr. Evershed's letter in NATURE of August 29 seems to me very suggestive, and it is to be hoped No. 2238 , VOL. 90] that his hypothesis may be tested by careful observation in many parts of the world. As regards the rarity with which these attacks have been witnessed in India by Mr. Evershed and many other naturalists, it is well to bear in mind the probability that the proportion of butterfly-eating birds differs in the different tropical regions. Indeed, it is difficult on any other hypothesis to understand why butterfly mimicry should be developed to such very different degrees in the three richest regions, being transcendent in the Neotropical, remarkable in the Ethiopian, but relatively poor in the Oriental region. Indirect evidence of the frequency of attacks in different areas might perhaps be obtained by a study of the relative amount of damage which could only have been inflicted by the beak of a bird.

St. Helens, Isle of Wight, August 26.

\section{A Flower-sanctuary.}

IN reply to Sir Edward Fry's inquiry (NATLRE, August 29, p. 66I) as to the powers of county councils to protect particular flowers, I am now enabled, through the courtesy of the clerk to the Cornwall County Council, to send a copy of the by-law referred to; it is given below. It is obvious that the Somerset County Council must possess the same powers as the Cornwall County Council, and that a by-law on these lines would meet the requirements of the case, and I venture to hope that Sir Edward Fry will exert his influence in favour of the enactment of such a by-law: Frank H. Perrycoste.

Higher Shute Cottage, Polperro, Cornwall, September 12.

County of Cornwall.-By-law for the Good Rule. and Government of the Administrative County of Cornwall, made in pursuance of the Local Government Act, I888, by the County Council of the said County, at a meeting held at Truro, on the 6th day of November, 1906, at which not less than two-thirds of the whole number of the Council were present:-

"No person shall (unless authorised by the owner or occupier, if any, or by law so to do) uproot or destroy any Ferns or other Wild Plants growing in any road, lane, roadside, waste, wayside bank or hedge, common, or other public place, in such a manner or in such quantities, as to damage or disfigure any such road, lane, roadside waste, wayside bank, or hedge, common or other public place. Provided that this by-law shall not apply to persons collecting specimens in small quantities for private or scientific use.

"Any person offending against this by-law shall be liable to a penalty not exceeding five pounds."

\section{THE SUMMER OF IOI2.}

THE summer of Igr 2 has proved so thoroughly unsummerlike, and has been so marked a contrast to the abnormally fine and hot summer of I9II, that a few facts may be of interest. The period dealt with will be limited to the three months June, July, and August.

The drought experienced in April, followed by a general deficiency of rain in May, rendered the early summer rains in June agreeable rather than otherwise, but the wet weather soon became too persistent, and the frequent rains have been a special feature of the past summer. With the exception of a period of eight days, July ro to $\mathbf{I}_{7}$, the weather throughout was unusually cold, and this was really the only dry period experienced over the country generally. 
The following table gives the summary of temperature, rainfall, and duration of bright sunshine issued by the Meteorological Office for the several districts of the United Kingdom for the past summer (thirteen weeks ended August $3 \mathrm{I}$ ), and the corresponding results for the summer of last year have been added:-

\begin{tabular}{|c|c|c|c|c|c|c|c|c|}
\hline \multirow{3}{*}{ District } & \multirow{2}{*}{\multicolumn{2}{|c|}{$\overbrace{\begin{array}{c}\text { Accumulated } \\
\text { number of } \\
\text { day degrees } \\
\text { above } 42^{\circ}\end{array}}^{\text {Temperature }}$}} & \multicolumn{4}{|c|}{ Rainfall } & \multicolumn{2}{|c|}{ Sunshine } \\
\hline & & & \multicolumn{2}{|c|}{$\begin{array}{c}\text { No. of days } \\
\text { with rain }\end{array}$} & \multicolumn{2}{|c|}{ Total fall } & \multicolumn{2}{|c|}{$\begin{array}{l}\text { Hours } \\
\text { recorded }\end{array}$} \\
\hline & I912 & rgri & rgrz & rgri & 1912 & IgIr & 1912 & rgert \\
\hline Scotland, North . . & 997 & I2II & s6 & 53 & $\begin{array}{l}\text { In. } \\
\text { 10 } 3^{8}\end{array}$ & In. & $29 \mathrm{r}$ & 476 \\
\hline \begin{tabular}{l}
\multicolumn{1}{c}{ Eastern } \\
Scotland, East . . \\
England, North-east \\
England, East : . \\
Midland Counties : \\
England, South-east
\end{tabular} & $\begin{array}{l}1063 \\
1284 \\
1553 \\
1371 \\
1524\end{array}$ & $\begin{array}{l}1370 \\
1679 \\
1911 \\
1832 \\
1940\end{array}$ & $\begin{array}{l}57 \\
65 \\
57 \\
60 \\
55\end{array}$ & $\begin{array}{l}43 \\
34 \\
29 \\
28 \\
24\end{array}$ & $\begin{array}{l}10.18 \\
12.86 \\
12.25 \\
13.28 \\
10.58\end{array}$ & $\begin{array}{l}5.78 \\
6 \cdot 64 \\
3 \cdot 83 \\
4^{\circ} \times 3 \\
3^{\circ} 3^{2}\end{array}$ & $\begin{array}{l}237 \\
309 \\
473 \\
346 \\
473\end{array}$ & $\begin{array}{l}574 \\
663 \\
759 \\
687 \\
838\end{array}$ \\
\hline $\begin{array}{l}\quad \text { Western } \\
\text { Scotland, West } \\
\text { England, North-west } \\
\text { England, South.west } \\
\text { Ireland, North. . . } \\
\text { Ireland, South. . }\end{array}$ & $\begin{array}{l}1213 \\
1314 \\
1369 \\
1105 \\
1237\end{array}$ & $\begin{array}{l}1477 \\
168 \mathrm{r} \\
1829 \\
1461 \\
1679\end{array}$ & $\begin{array}{l}58 \\
64 \\
65 \\
62 \\
70\end{array}$ & $\begin{array}{l}49 \\
39 \\
29 \\
45 \\
43\end{array}$ & $\begin{array}{l}12.45 \\
13^{\circ} .33 \\
16.74 \\
13.27 \\
15.04\end{array}$ & $\begin{array}{l}8.28 \\
6.74 \\
5.57 \\
7.29 \\
7.52\end{array}$ & $\begin{array}{l}364 \\
364 \\
382 \\
355 \\
373\end{array}$ & $\begin{array}{l}631 \\
705 \\
772 \\
565 \\
622\end{array}$ \\
\hline English Channel . . & 1510 & 1929 & 65 & 27 & $14^{\circ} 21$ & $5 * 49$ & 510 & $86 r$ \\
\hline
\end{tabular}

The foregoing table shows that the highest temperature during the past summer occurred in the east and south-east of England and in the Channel Islands, and the temperature for the recent summer is largely in defect of that last year in all districts. In the Midland counties and in the south-west of England the day degrees above $42^{\circ}$ are respectively $46 \mathrm{I}$ and 460 less than last year, which gives a deficiency of temperature of $5^{\circ}$ for the whole period compared with rgri. The deficiency of temperature this summer compared with that of I9I I exceeds $4^{\circ}$ in all the English districts except in the east of England, where it amounts to $3^{\circ} 9^{\circ}$.

The exceptionally heavy rains of August have greatly augmented the aggregate rainfall for the past summer over nearly the whole of Great Britain. At Darwen the fall for the month was $I^{\circ}{ }^{\circ} \mathrm{O}$ in. and at Norwich 10 $^{\circ} 5^{\circ}$ in., the latter being more than four times the average; of the large total at Norwich $7^{\prime} 34$ in. fell in the twenty-nine hours ending 9 a.m. August 27, and similar falls in the neighbourhood resulted in exceptionally severe floods. At Kew, the London reporting station of the Meteorological Office, the aggregate rainfall for August was 5.18 in., which is more than double the average, and it has only been exceeded once in August in the last fifty-seven years, 6.50 in. being measured in 1878 ; and there were only two days, the rst and the 9 th, absolutely without rain during the month.

The number of rainy days for the past summer is more in excess of the normal in the English districts than elsewhere, whilst the quantity of rain is largely in excess everywhere except in the north of Scotland, where it is seen from the table that the aggregate rainfall for the three months was less than in rar $\mathrm{r}$.

The returns for the summer show that the No. 2238 , VOL. 90] heaviest rainfall occurred in the south-west of England, where the measurement was 16.74 in., which is 8.17 in. more than the average of the last twenty-five years. In the Channel Islands the excess was 7.45 in., and in the Midland counties 6.23 in. The rainfall for the closing week of the season amounted to more than seven times the average in the east of England.

The duration of bright sunshine was everywhere largely deficient, and the table shows that the amount in the several districts is only about onehalf of that for the corresponding season in I9I I.

The following results from the Greenwich observations exhibit in a very striking manner the exceptional character of the past summer, and the results for the summer of I9I I are also given to show the contrast :-

\begin{tabular}{|c|c|c|c|c|c|c|c|c|c|c|c|c|}
\hline \multirow{3}{*}{ Period } & \multicolumn{6}{|c|}{ Temperature } & \multicolumn{4}{|c|}{ Rainfall } & \multirow{2}{*}{\multicolumn{2}{|c|}{$\overbrace{\begin{array}{c}\text { No. of } \\
\text { hours }\end{array}}^{\text {Sunshine }}$}} \\
\hline & \multicolumn{3}{|c|}{$\begin{array}{l}\text { Mean max. or } \\
\text { highest day }\end{array}$} & \multicolumn{3}{|c|}{$\begin{array}{l}\text { Mean min. or } \\
\text { lowest night }\end{array}$} & \multicolumn{2}{|c|}{$\begin{array}{c}\text { Days } \\
\text { with rain }\end{array}$} & \multicolumn{2}{|c|}{ Total } & & \\
\hline & 1912 & rgir & $\begin{array}{c}\text { Avge. } \\
70 \\
\text { Years }\end{array}$ & I912 & Igri & $\begin{array}{c}\text { Avge. } \\
70 \\
\text { Years }\end{array}$ & 1912 & 1911 & 1912 & $19 \mathrm{II}$ & 1912 & IgII \\
\hline $\begin{array}{l}\text { June } \\
\text { July : } \\
\text { August : }\end{array}$ & $\begin{array}{l}70 \\
75 \\
67\end{array}$ & $\begin{array}{l}71 \\
81 \\
8 x\end{array}$ & $\begin{array}{l}70 \\
74 \\
73 \\
73\end{array}$ & $\begin{array}{l}50 \\
55 \\
51\end{array}$ & $\begin{array}{l}50 \\
55 \\
57\end{array}$ & $\begin{array}{l}50 \\
53 \\
53\end{array}$ & $\begin{array}{l}18 \\
1 \pi \\
26\end{array}$ & $\begin{array}{r}12 \\
3 \\
8\end{array}$ & $\begin{array}{l}\text { In. } \\
2.34 \\
x \cdot 25 \\
4.38\end{array}$ & $\begin{array}{l}\text { In. } \\
2^{*} \text { II } \\
0 \cdot 26 \\
r^{*} 35 \\
\end{array}$ & $\begin{array}{l}219 \\
164 \\
114\end{array}$ & $\begin{array}{l}224 \\
335 \\
260\end{array}$ \\
\hline ummer. & $7 x$ & 78 & 73 & 52 & 54 & 52 & 55 & 23 & 7.97 & $3: 72$ & 497 & 819 \\
\hline
\end{tabular}

It is seen that August is in every way the most exceptional of the three recent summer months. The mean of the day temperatures is $14^{\circ}$ lower than in August, I9II, and the mean of the night temperatures is $6^{\circ}$ lower. There were only five days without measurable rain, both the rainy days and the amount being more than three times as great as in I9II, whilst the duration of bright sunshine was less than one-half.

There were twelve days in the past summer with a shade temperature of $80^{\circ}$ and above, whilst in the summer of I9I I there were thirty-seven such warm days, the average for the last seventy years being thirteen days. There were forty-five days this summer with the temperature $70^{\circ}$ or above, and in the summer of I9I I there were seventythree days with that temperature, the average for the past seventy years being fifty-nine days. The highest shade temperature in August this year was $73^{\circ}$, whilst in August last year it rose to $100^{\circ}$, the reading being a record for Greenwich.

The controlling factor of the weather over the British Isles during the past summer has been the unusual distribution of atmospheric pressure in our neighbourhood. During almost the whole of the summer a region of high barometer has been situated in the Atlantic to the south-west of our area, and a second region has been situated either over Iceland or Scandinavia. This has left a free passage over the British Isles for incoming disturbances from the Atlantic, and these have become imprisoned within our area, moving very sluggishly on their easterly track, and at times remaining practically stationary.

A feature of especial interest due to the unusual wind circulation set up by the abnormal atmospheric distribution was the exceptionally high temperatures which prevailed over Scandinavia 
during the first half of August, whilst in the British Isles and in other parts of western Europe the weather was peculiarly dull and cold. For the week ending August 12, the mean of the maxima or highest day readings at Haparanda was $80^{\circ}$, at Bodö $74^{\circ}$, and in London and at Jersey $63^{\circ}$; whilst at Lisbon the mean was only $76^{\circ}$, and at Nice $78^{\circ}$.

The temperature of the sea-surface in the North Atlantic and in proximity to our coasts has for some time past been much below the average.

Chas. Harding.

\section{CHIRIQUIAN ANTIQUITIES. ${ }^{1}$}

PROF. G. G. MacCURDY, of Yale University, has taken advantage of the fine collection of antiquities from Chiriqui under his charge to present to students a very valuable and interesting monograph, which is illustrated, in the usual lavish and artistic manner of our colleagues in the United States of America, by 384 figures in the text, 49 plates (five of which are coloured), and a map. The ancient cultured people of Chiriqui are apparently represented by the Guaymi, whose language shows affinity with that of the Chibcha of Colombia. The area now occupied by the republics of Colombia and Panama formed a linguistic and archæological barrier between the great civilisations of Mexico and Peru. In this culture zone the dominant factor is Chibchan; on the other hand, the ancient art of Chiriqui was influenced more by Mexico than by the south, but the Chiriquian culture was distinctively indigenous, and radiated into southern Costa Rica.

Attention is directed throughout the memoir to the general phylogenetic trend in the development of Chiriquian art as a whole. The elegant stone vessels carved in the form of a jaguar are traced back to an oval prototype with a hollow pedestal; with the exception of architecture, the stone art of Chiriqui compares favourably with that of Mexico or Peru. The especial interest of Chiriquian pottery was first emphasised by Prof. W. H. Holmes (Sixth Ann. Rep. Bur. Am. Ethnol., 1888), and Dr. MacCurdy has with slight modifications adopted his classification. The pottery, especially the unpainted ware, is the connecting link between the products of the stone worker and artificer in metal. The "prototype was presumably the calabash. Aside from this, the plant world had practically no influence on the elaboration of form and ornament." The unpainted ware includes the terra-cotta or biscuit group, or, as MacCurdy prefers to call it, the armadillo group, as its ornamentation is mainly based on the armadillo, and three smaller groups.

The painted ware consists of ten groups, of which the fish or tripod, lost colour, alligator, and polychrome groups are the most important (Fig. I). As might be anticipated, the introduction of colour as a decorative factor often tended to mini-

1 "A Study of Chiriquian Antiquities." By Prof. G. G. MacCurdy. (Memoirs of the Connecticut Academy of Arts and Sciences, vol. iii., March, rgir.) Pp. $x x+249+x l i x$ plates. (New Haven, Conn. : Yale University
Press, rgir.)

$$
\text { No. } 2238 \text {, VOL. 90] }
$$

mise the importance of incised and plastic features; the armadillo and serpent are practically never executed in paint, while incised or plastic motives derived from the alligator are equally rare. Very characteristic of Chiriquian pottery is the presence of three hollow legs, provided with long slits and containing pellets, which serve as a rattle; most of these in the painted ware have a fish ornamentation. The lost colour process was confined to a single, rather large, group of ware; it consisted of tracing the design in wax, the application of a solid coat of black paint over the area to be decorated, and immersing the vessel in hot water, which melted the wax, the design part that was waxed thus showing up light. An analogous method is employed in Java for decorating sarongs.

In the alligator group the designs are always on a pale yellow slip; black and red are the delineating colours. As a matter of fact, it is the crocodile, and not the alligator, which is depicted. The modifications which occur in the form of the crocodile or of parts of it constitute a very pretty

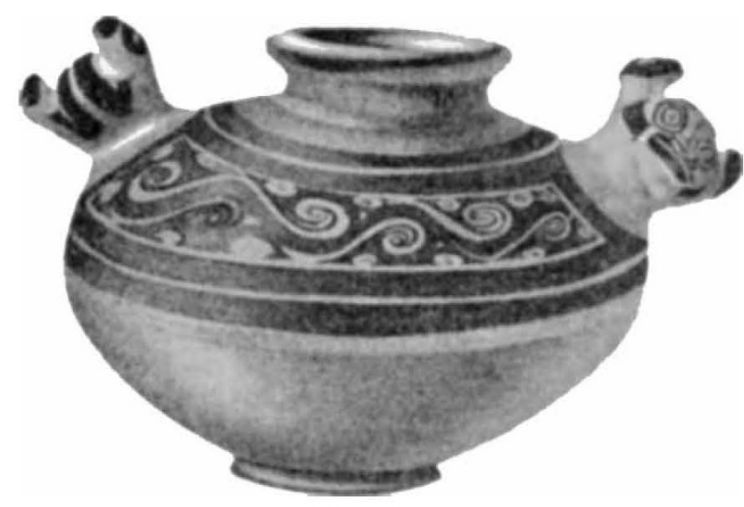

FIG. 3.-Polychrome ware. Vase of eccentric form, the chief ornamental feature being the elaborate branching scroll filling each of the two shoulder panels; the engaged crocudile motives are easily distinguished.

example of the conventionalisation of designs. The highest technical excellence was achieved in the polychrome group; here a purple colour was introduced derived from a non-ferruginous metallic oxide, and not from the Purpura patula, which was used to dye cotton thread; it is also characterised by elegant scroll designs derived from crocodiles. The gold Chiriquian figurines are famous, and are here treated adequately for the first time. Squier (1859) says he "was informed by the late Governor of the Bank of England that several thousand pounds' worth were annually remitted from the Isthmus as bullion to that establishment," where they were melted down.

\section{A. C. HadDon.}

THE BRITISH ASSOCIATION AT DUNDEE.

$\mathrm{NE}$ of the most successful meetings of the British Association in recent years, and the largest since the Cambridge meeting of I904, when the total attendance was 2789 , in comparison with about 2500 at Dundee, was brought to a close as we went to press last week. A distinguishing and pleasing characteristic of the meeting was 